\author{
Abdoul-Aziz Issa Daouda \\ Abdoul-Aziz Issa Daouda teaches \\ in the Department of Modern \\ literature, Abdou Moumouni \\ University of Niamey (Niger). He \\ specialises in Nigérien Literature \\ and teaches contemporary French \\ Literature and literary criticism. \\ E-mail:idaziz@yahoo.com
}

\title{
Two favourite themes in Nigérien literature
}

\section{Two favourite themes in Nigérien literature}

Critics tend to generalise in their analysis of African literature by presenting it from two main angles: anti-colonial literature and the literature of disenchantment focused on a criticism of the political regimes that came out of independence. However, not only did Nigérien literature emerge after independence, but writers from Niger tend to emphasise certain themes addressing practical concerns that are specific to their community; they do not focus on political satire per se. Hence, Niger's novelists pay attention to essential themes like drought and famine, rural exodus and emigration. Such themes, while constituting the originality of their writing, unfortunately also preclude the usual generalisations of which critics are so enamoured. Key words: Nigérien novel, drought, famine, rural exodus / migration, emigration.

A literary work is not the product of a gratuitous act outside the bounds of time and space; it can only be explained by the creative genius of an individual who wrestles with a reality that determines him (or her), who belongs to a social and historical environment to which $\mathrm{s} / \mathrm{he}$ reacts and on which $\mathrm{s} / \mathrm{he}$ in turn acts. The literary act is therefore an eminently social act, which cannot be reduced to a bare text, a closed circuit, whose meaning and justification are confined to itself. To reduce the cult of the text to abstract formalism is to deny its ideological and social function (Siddo Issa, 1977).

\section{Introduction}

Nigérien literature, like other national literatures in Africa, gives prominence to certain recurring themes. These express the concerns of the local populations: their joys and hopes, their anguish, even their sense of failure. This literary function is not new in Africa, for, before the advent of writing, ancestral oral literature aspired to be the mirror of society, whose values, anxieties and world view it translated and continues to translate.

This desire to hold a mirror up to society can be seen in the works of the "modern" writers, through their depiction of colonial and postcolonial societies. Therefore, it is not surprising that criticism of this literature adopts a militant perspective. "Classical”, it often opts for a 
thematic approach and concentrates mainly on the colonial period, in the case of anti-colonial and committed (engagé) works, and on the post-independence period, as far as more contemporary works, termed "of disenchantment", are concerned (Dabla, 1986).

However, this thematic-historical presentation is not innocuous; the main danger being that it overlooks certain national productions, such as the novels of Niger. In fact, the history of Niger has unique characteristics, and its literature, which is still young, does not always follow the general tendency of enthusiasm and commitment to independence and of post-independent disenchantment.

This does not prevent certain Nigérien novels, such as Gros plan (Close-up, 1976) and Le Représentant (The representative, 1977) by Idé Oumarou, Quinze ans ça suffit! (Fifteen years are enough!, 1977), and Le Nouveau Juge (The new judge, 1982) by Amadou Ousmane from contributing to the African theme of disenchantment (expressed by the satire of post-independent political institutions), while the novels Kotia Nima (Listen child, 1969) and Bikado (1971) by Boubou Hama, or Sarraounia (1980) by Mamani Abdoulaye, written after independence, evoke the colonial situation (at a time when the trend in African novels was already one of disenchantment).

In general, the thematic choice of certain novelists is inspired by different sources and periods, that run counter to typologies that are often reduced to thematic perspectives like cultural conflicts (négritude), anti-colonial revolt and the disenchantment or disillusionment of African writers in the face of the performance of the regimes that emerged after independence. This disappointment is often expressed through political satire, visible in the African novel, starting in the 1970s.

Such a categorisation into two major African themes would, for obvious reasons, make it difficult to reveal the originality of a narrative production created since independence. Indeed the principle of a literature that "mirrors society" inevitably leads to the famous equation of Sainte-Beuve: tel arbre, tel fruit (a tree can only bear its own fruit). In other words, every society, because of its own specific characteristics, generates a particular literature. Indeed, as Emmanuel Dongala puts it, "If it is legitimate to speak of an African literature, it is even more obvious that the countries, formerly seen as homogeneous, have become more and more differentiated with the passing years, and every one generates from its own society divergent concerns or at least priorities, in accordance with the type of political regime they have experienced" (in Chevrier, 1984: 9). ${ }^{1}$ 
The spirit of this statement is understandable, but it also seems possible to say that (Francophone) African countries have had a political history that is similar in many ways. This more or less common experience is reflected in the novels of francophone Africa. Consequently, it appears possible, as far as the novel is concerned, to emphasise a shared set of themes, accompanied by a few divergent details.

However, in the case of the novels of Niger, it seems distinctly more appropriate to look for thematic specificity. The latter is in part the result of the country's particular climatic conditions (hot, dry and semiarid, with no access to the sea) and their effect on the day-to-day life of local societies. It is obvious that the economic life and the social and political concerns of a Sahelian country like Niger are not those of a country blessed with more favourable climatic (and economic) conditions. (It is likely that the same principle has probably led to the emergence of similar thematic choices in other Sahelian countries with which Niger shares analagous climatic conditions). Nevertheless, a new thematic horizon becomes apparent in the works of Nigérien novelists, in which subjects like drought, famine, rural exodus and emigration often recur, whether or not these form the central element of their works.

\section{Drought and famine}

\section{Sources of inspiration}

The Sahel, the sub-Saharan region to which Niger belongs, is characterised by the quasi-aridity of its soils. Added to this is the problem of inadequate rainfall, in a context in which the populations depend for their survival essentially on rainfall agriculture and extensive cattle rearing (Ossolo, 1975).

The recent history of the country bears witness to several instances of drought and famine. These phenomena, due to their traumatising effect and the impression they have made on the imagination of Nigériens, have become temporal points of reference. Thus, in Niger, where births are not always registered, a person born in 1954, for example, is said to be from "the year of the cassava famine" or Garo jire in the Zarma language. During this famine of 1954, one of the most catastrophic in the history of Niger, the people managed to survive mainly thanks to cassava flour, a food until then unknown, imported from neighbouring Bénin. In local languages a person's "date of birth" is often situated in relation to climatic crises: such and such a person, we are reminded, was born in "the year of the locust", Dwa jire, which relates to the great famine of 1931-1932. 
Oral literature, because of its social function, was for a time naturally drawn to the themes of drought and famine. For the poet or singer, evoking drought or famine was to express personal and collective suffering. However, it was also a question of appealing to the sense of sharing, of promoting awareness and instilling the positive social attitudes of solidarity and goodwill. The following extract from a popular song illustrates this.

Famine is here

Famine is here

No more singing

No more dancing

Only weeping

But there are no more tears

Famine is here

Famine is here

The time for brotherhood is here

Famine is here

Your grain of millet

Don't hide it, let's eat it...

If you win, I will benefit

If I win, you will benefit

(Anonymous text, undated, recorded by Bania Mamadou Say.) ${ }^{2}$

It is interesting to note that the appeal for solidarity reflected in this kind of lament corresponds to a "poeticising of misfortune", for the pathos of the song is meant to have an effect, as if the poet-singer wanted, through his poetry, to exorcise the evil of famine. Later, with the advent of writing, modern poets would adopt the same approach as their elders, whereas novelists would reject it in the name of "realism", tinted with polemical overtones. Instead of the rather "discreet" suggestions made by poets, novelists prefer to develop the themes of drought and famine, using them as a pretext for criticising political regimes they consider to be responsible for these disasters, or at least guilty of the aggravating consequences. This is notably what Amadou Ousmane does in Quinze ans ça suffit!. The dignitaries of the regime are accused of misappropriating the provisions of international cooperation when the Republic of Bentota was experiencing the worst drought of its existence.

Although there have been many droughts and famines in Niger, it is especially the drought of 1973 and the great wave of famine it engendered that seem to have inspired Nigérien novelists. At that time, Niger, 
like the whole of the Sahel, experienced some of the most tragic moments of its history. The rains the populations depend upon did not come. Waiting in vain, the peasants tried to survive on cereal reserves from the previous year. When the granaries were empty, the livestock was decimated. When one reads works that evoke this period, the compassion of the authors for the many victims, commonly called in the media "the afflicted of the Sahel" (les éprouvés du Sahel), shines through in their treatment of the themes linked to the drought and famine of 1973. Writing thus becomes a testimony of solidarity addressed by the novelist to his compatriots.

This is the case of Ada Boureima, whose novel Le baiser amer de la faim (The bitter kiss of hunger) has the following dedication: "To all those who suffer or have suffered famine, I dedicate this little book as a sign of solidarity". ${ }^{3}$ However, if the year 1973 symbolises the tragedy of drought and famine, it also represents above all, through the disillusioned gaze of the novelists, the fifteen years of the reign of the First Republic of Niger, between 1959 and 1974, marked by the government of the PPN-RDA, the Parti progressiste nigérien pour le rassemblement démocratique africain (Progressive Nigérien Party for Democratic African Unity).

\section{From poetic lament to novelistic satire}

As mentioned above, poets and novelists did not have the same approach to these social realities: the former became the bards of suffering, while the latter preferred to reveal the manipulations of those whose objective (sometimes achieved) was to profit, in the most mercenary sense of the word, from the misfortunes of others. Here is a quick sample of the two approaches.

First, let us sample Boubé Zoumé's lament " $\mathrm{O}$, frères et sœurs eprouvés!" ("Oh, my afflicted brothers and sisters!") in Les souffles $d u$ cœur (The inspirations of the heart, 1977).

Oh, brothers and sisters!

I weep!

Alone, I weep for you in silence

This is the utmost pain of the soul!

I weep!

And I wonder why it had to be

That we should eat our fill,

Why it had to be that you should die

Of hunger and thirst alongside us 
There, I have no millet to fill the pot-bellied granaries!

There, I have no fresh milk for the orphans!

Neither do I have a drop of water to slake

Your throats on fire, but I offer you

What I treasure most in this world:

A poem of the utmost pain of the soul.

I weep

(...)

I weep for you, I sing of you!

(Zoumé, 1977: 40) ${ }^{4}$

One can better appreciate the manner in which the novelists deal with the themes of drought and famine when a comparison is made with such a poem. The poet, without trivialising the disaster, evokes it by internalisation. The word "hunger" (faim) is only used once; the tragedy of the afflicted is contained and transformed into a personal emotion, into a "pain of the soul" (douleur de l'âme). Boubé Zoumé demonstrates his solidarity with the afflicted, he weeps for them by singing of them, but in "silence" (silence). There is a deliberate reticence, a sense of propriety in the poetic evocation, a certain dignity that is the opposite of lyrical effusion. It can be noted that the poet proceeds here in the same way as the storyteller, singing of the "evil" (mal) to make it less traumatic, more bearable.

In the novel, on the contrary, the object is to describe the disaster by deliberately exaggerating it. Amadou Ousmane's novel Quinze ans ça suffit! is an example of this treatment. The novelist gives a description of the drought and famine intended to shock the reader as much as possible. He evokes the catastrophe in these terms: "Famine? What famine? You should picture a scourge, something like the plague in the Middle Ages. The living dead adrift, wandering among corpses piled high, a country devastated" (Ousmane, 1977: 30). ${ }^{5}$

Ali, the son of the protagonist, on returning from France, reads these words in a newspaper article. The horror of the report makes him think it is a case of the "exaggeration of a certain press" (l'amplification d'une certaine Presse) despite the fame of its Parisian author. For Ousmane, it was a matter of ascribing the responsibility of the crisis to the leaders of the country, whom he reproached for their lack of concern. Then the misfortune is magnified in a tendentious description of destitution, against the background of the tragic misappropriation of provisions 
that international institutions had placed at the disposal of the afflicted populations. The themes of drought and famine are therefore, in his works, pretext themes that the Nigérien novelist uses to denounce the government of the First Republic of Niger. There is no doubt a testimony of solidarity for the victims of the drought, but it is nevertheless subordinate to the importance given to the political satire.

\section{Rural exodus and emigration}

In the Nigérien novel, the themes of rural exodus and emigration are often linked to the disasters of drought and famine, for it is these kinds of crisis that bring about the departure of the protagonist. This is true for Waay dulluu (1981) by Ada Boureima and Abboki, ou l'appel de la côte (Abboki, or the call of the coast, 1978) by Mohamadou Halilou, in which the departure in search of adventure is the main subject.

\section{The tragedy of the peasant's world}

In the novels that interest us here and that explore this problem, the hero's drama is the result of a painful choice: should he go or stay? To depart means to go towards unknown places: the city or a foreign land. It also implies a break with the familiar world where he was born, even if this is a place in which "the earth has broken the pact that connected it to men" (la terre a rompu le pacte quile liait aux hommes) by its lack of productivity. To leave therefore entails some anguish in the hero, as Gambo, the main character in Waay dulluu, admits "I left my father with a heavy heart, in spite of my ardent desire to get away" (Boureima, 1981: 7). ${ }^{6}$

However, to stay seems just as problematic, just as unbearable. This is the case, in particular, in Abboki. In this novel, the hero, Amadou, decides to set off in search of adventure, not only to ensure the survival of his family in times of famine, but also above all to save them from the humiliation of being unable to pay their taxes.

Then tragedy struck when a peasant, having paid the amount due, swore by all the gods that he did not have the additional few hundred francs. The only response he received was a sound beating accompanied by a torrent of curses. My father was next. Of the total amount owing, he was five hundred francs short. Instead of an explanation, the district chief slapped his face hard. The guards, for their part, were going to grab him to whip him (Halilou, 1980: 13). ${ }^{7}$

Novelists tend to emphasise, from the outset, the unhappy situation of the protagonists in order to highlight the hope that motivates their 
departure for the city or a foreign country. Thus, in the introduction to Abboki, to leave is seen as a panacea, for the emigrants, "wanting to flee the poverty of their native soil, set out for the towns on the coast in search of better tomorrows" (Halilou, 1980: 5). ${ }^{8}$ But the novelist does not let any doubt subsist as to the failure of his hero; the end comes as no surprise: from the beginning, the reader knows that Amadou's hope will be frustrated. In Waay dulluu also, Gambo very soon realises that his quest will be in vain and informs the reader of his intuition.

I knew Hwada [the city] (...) I went there following the example of other boys of my age and, well, luck smiled on me: after only two moons, I returned to the village and gave the chief two months' taxes for my whole family. But, I was far from suspecting that luck, dangerously bald, only had one hair and that I had just plucked it (Boureima, 1981: 11). ${ }^{9}$

To make the protagonist's adventure end in failure seems to point to the defence of the rural world. For Ada Boureima, it amounts to exposing the pitfalls of the city, the most fatal of which is certainly criminality in all it forms. As for the novel of Mohamadou Halilou, Abboki, it becomes a dramatisation of the isolation and rejection experienced by the Nigérien peasant who is an immigrant in a foreign land. This excommunication is summed up in the nickname meant to be insulting "Abboki" given to the hero and his compatriots on the "coast" (côte), (in Côte d'Ivoire). But the exodus is also a loss for the country, "every year, after the harvests and sometimes even before, several of our regions are emptied of their able-bodied workers" (Halilou, 1980: 5). ${ }^{10}$ Hence, the insistence of the novelists on the disastrous effects, in an effort to dissuade those wanting to leave.

\section{The trap of the city}

Departure in the Nigérien novel, regardless of the destination, is therefore often synonymous with misfortune. In the case of Amadou, the protagonist of Abboki, ou l'appel de la côte the setbacks begin, before the character reaches the "coast", in the form of harassment at the hands of greedy policemen. The first misadventure is followed, once he arrives at his destination, by the suffering of the exiled peasant in the face of the indifference of the citizens of the foreign country in which he lands. Then he becomes aware of his status as a foreigner in a world peopled with blacks. His unhappiness can be measured in terms of distance, for not only is Gambo far from home, he is no longer able to feel close to his 
cousin Manou, despite having spent his whole childhood with him. The latter has also become a Hwadaizé, a "child of the city", and privy to a world that the young peasant cannot understand and whose operating systems he fails to master. Gone are the warmth and solidarity of the village. However, the hero must adapt to the best of his ability to the coldness and indifference of the city, so as to become, perhaps, in his turn a Hwadaize, "Manou had not been lying: in Hwada, nobody worried about anybody, nobody was interested in anyone else, everyone was intent on furthering his own cause and cared nothing about the problems of others! He and I hardly ever saw each other any more" (Boureima, 1981:31). ${ }^{11}$

Just like Gambo, Amadou is quickly disillusioned. He has difficulty in accepting the fact that he is a foreigner in a country of black people, Africans like himself. Moreover, he cannot understand the curses levelled at him: "Dirty Abboki! You thief-Scoundrel, go back where you belong! You're all parasites! You come here to take the food out of our mouths! Lousy good-for-nothing, clear off!" (Halilou, 1980: 27). ${ }^{12}$ But he quickly realises his new status, "At last I understand, he said, that I am in a foreign land. My heart heavy with sorrow, I went back to my companions and told them the sad tale of my misadventures" (Halilou, 1980: 27). ${ }^{13}$ However, if the narrator-protagonist accepts with resignation and sadness the dejection that goes with his foreign status, he finds it more difficult to accept the disillusion of frustrated hopes.

The structure of the plot is practically the same in all the novels. A departure full of hope is followed by numerous failures, resulting in the loss of hope, redefined as illusion, and the return, in the end, to the homeland or village. Nevertheless, the return is not the re-establishment of the status quo, for the character-narrator finds that he is even worse off than he was before he left. It sometimes happens before the return that, when the awakening occurs, when the migrant (or emigrant) realises that his hopes were just wild dreams, the disappointment is so bitter that he gives in and slides down the slope of criminality. This is what happens to the protagonist in Waay dullu:

After having managed, for eight years, without an identity card and without a profession, to evade the innumerable traps set by the police commissioner in charge of dealing with vagrants like me, who did not know where their true happiness lay, I was caught - oh the irony of fate - with my hand in the pocket, about to steal the wallet, of an old herdsman who had come to sell his animals at the big cattle market of Hwada (Boureima, 1981: 50). ${ }^{14}$ 
The return represents the final ordeal of the journey of the narratorprotagonist of this kind of novel. It is filtered through feelings of failure and regret. Amadou returns to his homeland, poorer than ever and with one leg amputated, while Gambo goes back to his village after having served a prison sentence, with the added pain of the loss of his only son. Hence the pathetic summary of his adventure: "The bird came back to its nest, he will sadly say, but it had lost all its feathers" (Boureima, 1981: 50). ${ }^{15}$ In any event, the narrative revolves around the bitter acknowledgement of failure. The character-narrator distances himself from his unhappy past in order to judge himself with the greatest severity. As a spokesman for the rural world, however, he goes beyond the individual aspect of his experiences, of his adventure (or misadventure), to give a moral lesson of general import; in the course of which he reveals, for the benefit of rural youth, the harsh realities of migration and emigration to the city or another country, while examining the relations between the rural and urban worlds.

\section{Conclusion}

At the end of this rapid review of the relationship between the climate (meteorological and political) and the Nigérien novel (essentially focused on the aesthetic exploitation of the phenomena of drought and famine, linked to rural exodus and emigration), it can be seen that the various themes reveal certain specific characteristics of local expressions of this genre. The Nigérien novel challenges the practice of generalisation adopted by criticism that sees African literature as synonymous either with anti-colonialism or violent indictments against postindependence political regimes. By favouring these thematic typologies, especially in anthologies, critics have contributed to an inadequate and sometimes erroneous appreciation of certain "emerging national literatures" (littératures nationales émergentes), such as that of Niger, whose writers seldom draw their themes from obsessive political denunciations. The Nigérien novelist of this generation often chooses to commiserate with the afflicted populations of Niger and Sahel, continually confronted with poor rainfall and its consequences: inevitable rural exodus, emigration and the identity crises they provoke. Consequently, the Nigérien novel should be seen as a "Sahelian novel" (roman sahélien) rather than as an "African novel" (roman africain). 


\section{Notes}

1. "S'il est légitime de parler d'une littérature africaine, il est plus évident que les pays, autrefois uniformisés, se sont de plus en plus différenciés par les années qui passent, et chacune de leur société engendre des préoccupations ou du moins des priorités divergentes, suivant le type de régime politique qu'elles subissent" (Dongala in Chevrier, 1984: 9).

2. "Harey ka/ Harey ka/ dooni ban/ gaani ban/ kaladay mundi/ Amma mundi si/ Harey ka/ Harey ka/ Care diyan ka/ Harey ka/ ni hayni gura din/ sa tugu in ma'kaama/ Din du kulu ay du/ Hal ay du mo ni wane."

3. "À tous ceux qui souffrent ou ont souffert de la famine, je dédie ce petit livre en guise de solidarité."

4. “Je pleure!/ Seul, je vous pleure dans le silence/ C'est l'extrême douleur de l'âme!/ Je pleure!/ Et je me demande pourquoi il fallait/ Que nous mangions bien à notre aise;/ Pourquoi il fallait que vous mouriez/ De faim et de soif à côté de nous./ Voilà, je n'ai pas de mil pour charger les greniers pansus!/ Voilà, je n'ai pas de lait frais pour les orphelins,/ Je n'ai pas non plus une goutte d'eau pour adoucir/ Les gorges en feu, mais j'ai à vous offrir/ Ce que je possède de plus cher en ce monde:/ Le poème de l'extrême douleur de l'âme.// Je pleure/(...)/ Je vous pleure, je vous chante!"

5. "La famine? Quelle famine? Vous imaginez un fléau, quelque chose comme la peste au moyen âge. Des morts-vivants à la dérive, errant parmi des amoncellements de cadavres, un pays foudroyé" (Ousmane, 1977: 30).

6. “Je quittai mon père, le cœur serré, malgré mon désir ardent de partir" (Boureima, 1981: 7).

7. "Alors le tragique se produisit au moment où un paysan ayant versé la somme due, jura par tous les dieux ne pas posséder les cents francs supplémentaires. Pour toute réponse, il reçut une belle raclée qu'accompagnait un flot d'injures. Mon père lui succéda. Sur le montant total, il lui manquait cinq cents francs. Pour toute explication, le chef de canton lui appliqua une belle gifle. Les gardes, de leur côté, allaient se ruer sur lui pour le cravacher" (Halilou, 1980: 13).

8. "pensant fuir la misère du terroir natal, partent en quête de lendemains meilleurs vers les villes de la côte" (Halilou, 1980: 5).

9. “Je connaissais Hwada [la ville] (...) J'y allai à l'instar d'autres garçons de mon âge et la chance, ma foi, me sourit : après seulement deux lunes, je reviens au village et remis au chef deux mois d'impôt pour toute ma famille. Mais, j'étais loin de me douter que la chance, dangereusement chauve, n'avait qu'un cheveu et que je venais justement de l'arracher" (Boureima, 1981: 11).

10. "chaque année, après les récoltes et même parfois avant, plusieurs de nos régions se vident de leurs bras valides" (Halilou, 1980: 5).

11. "Manou ne mentait pas: à Hwada, personne ne s'occupe de personne, ne s'intéresse à personne, chacun cherche à fructifier ses affaires et se soucie peu des problèmes des autres ! Lui et moi ne nous voyions presque plus maintenant" (Boureima, 1981: 31).

12. "Sale Abboki! Espèce de voleur - Mécréant, retourne chez toi! Vous êtes tous des parasites! Vous venez chez nous pour nous affamer! Vilaine vermine, décampe de là!" (Halilou, 1980: 27).

13. "Je compris enfin, dit-il, que je me trouvais en terre étrangère. Le cœur gros de chagrin, je rejoignis mes camarades auxquels je fis un triste compte-rendu de mes mésaventures" (Halilou, 1980: 27).

14. "Après avoir, durant huit ans, sans carte d'identité et sans profession, pu éviter les nombreux pièges que tendait le commissaire aux vagabonds de mon espèce, qui ignoraient où se trouvait leur vrai bonheur, je fus pris, ô! Ironie du sort, la main dans le sac, alors que je m'apprêtais à délester de son portefeuille, un vieux berger venu vendre ses animaux à l'important marché de bétail de Hwada" (Boureima, 1981: 50).

15. "l'oiseau revenait dans son nid, dira-t-il mélancoliquement, mais il avait perdu toutes ses plumes" (Boureima, 1981: 50).

\section{Bibliography}

Amadou, Diado. 1972. Maïmou ou le drame de l'amour. Niamey: Edition du Niger.

Anonymous. n.d. Harey ka. Bania Mamadou Say (Recording).

Boureima, Ada. 1981. Waay dulluu ou l'étau. Niamey: NIN. . n.d. Le baiser amer de la faim. Niamey, Imprimerie Nationale du Niger.

Boureima, Alpha Gado. 1983. Sécheresse et Famines au Sahel les famines dans le Zarmatarey et le songhay de 1880 à 1973. Mémoire de maîtrise, non publié, Université de Niamey, Université de Paris VII. 
Chévrier, Jacques. 1984. Littérature nègre. Paris: A. Colin.

Dabla, Séwanou. 1986. Nouvelles écritures africaines. Paris: L'Harmattan.

Dan-Inna, Chaïbou \& Penel, Jean Dominique. 1988. Bibliographie de littérature nigérienne. Niamey: INN.

Halilou, Sabbo Mohamadou. 1980. Abboki, ou l'appel de la côte. Dakar: NEA.

Idé, Adamou. 1987. La camisole de paille. Niamey: INN.

Issa Daouda, Abdoul-Aziz. 1993. La double tentation du roman nigérien. Thèse de doctorat, non publié, Université Paul Valéry, Montpellier III.

Issa, Siddo. 1977. La problématique littéraire en Afrique. Les responsabilités de l'écrivain africain. Paper read at Colloque sur la littérature africaine au Festival Africain des Arts et Culture (FESTAC), Lagos (Nigeria).

Mounkaila, Fatima. 1989. Le mythe et l'histoire dans la geste de Zabarkane. Niamey: CETHO.

Ossolo, J. 1975. Un territoire de mare au Sahel, (Niger Occidental). Thèse pour le doctorat es lettres et sciences humaines, Université de Haute Normandie.

Ousmane, Amadou. 1977. Quinze ans ça suffit! Dakar: NEA.

Zoumé, Boubé. 1977. Les souffles du cœur. Yaoundé: Edition Clé. 